\title{
Shifting paradigms in the approach to footstrikes, footwear and treatment of the foot
}

Irene Davis

\section{From Australasian Podiatry Council Conference 2011}

Melbourne, Australia. 26-29 April 2011

The recent rise in popularity of barefoot and minimal footwear running has led to spirited debates within the scientific, clinical and public arenas. While there are no definitive injury studies that support barefoot over shod running, there is a growing body of literature that suggests we may need to change our thinking about running mechanics, footwear and how we treat the foot. This presentation will review existing studies of the relationship between shod footstrikes, mechanics and injury. In addition, the direct effect of footwear on mechanics will be discussed. Finally, this evidence will also be used to suggest a change in our approach to common foot related pathologies. It is hoped that this presentation will be a catalyst for changing the way we view these issues.

Published: 20 May 2011

doi:10.1186/1757-1146-4-S1-A3

Cite this article as: Davis: Shifting paradigms in the approach to

footstrikes, footwear and treatment of the foot. Journal of Foot and Ankle

Research 2011 4(Suppl 1):A3.

Submit your next manuscript to BioMed Central and take full advantage of:

- Convenient online submission

- Thorough peer review

- No space constraints or color figure charges

- Immediate publication on acceptance

- Inclusion in PubMed, CAS, Scopus and Google Scholar

- Research which is freely available for redistribution
Biomed Central 